Int. J. Electrochem. Sci., 14 (2019) 9711 - 9725

\title{
Effect of AC Interference on Corrosion Behavior of X100 Pipeline Steel with Different Microstructure in Alkaline Soil Environment
}

\author{
Min Zhu*, Jun Ma, Yongfeng Yuan, Shaoyi Guo \\ School of Mechanical Engineering \& Automation, Zhejiang Sci-Tech University, Hangzhou 310018, \\ PR China \\ *E-mail: zmii666@126.com
}

doi: $10.20964 / 2019.10 .24$

Received: 24 May 2019 / Accepted: 31 July 2019 / Published: 30 August 2019

\begin{abstract}
Alternating current (AC) corrosion behavior of X100 pipeline steel with welded joint in simulated solution of Golmud alkaline soil was studied by electrochemical tests, immersion test and surface analysis technique. Without the presence of $\mathrm{AC}$ or at the low $\mathrm{AC}$ current densities of $30 \mathrm{~A} \cdot \mathrm{m}^{-2}$ and $50 \mathrm{~A} \cdot \mathrm{m}^{-2}$, oxygen consumption reaction controls the entire cathode process. While cathode process is dominated by hydrogen evolution reaction at high AC current density of $150 \mathrm{~A} \cdot \mathrm{m}^{-2}$. With or without $\mathrm{AC}$ application, X100 steels with different microstructure have various corrosion resistances, and the corrosion resistance of steels is in the order of normalized $>$ hot rolled $>$ annealed. The pearlite and granular bainite in the steel have high electrochemical activity, where pitting corrosion generally easy to occur. The combined action of temperature and AC current density promotes the corrosion of X100 pipeline steel to a certain extent. At the low AC current density, the effect of temperature on corrosion behavior is more notable. While the $\mathrm{AC}$ current density increases up to $150 \mathrm{~A} \cdot \mathrm{m}^{-2}$, the $\mathrm{AC}$ corrosion plays a dominant role.
\end{abstract}

Keywords: X100 steel; Microstructure; AC interference; Corrosion behavior

\section{$\underline{\text { FULL TEXT }}$}

(C) 2019 The Authors. Published by ESG (www.electrochemsci.org). This article is an open access article distributed under the terms and conditions of the Creative Commons Attribution license (http://creativecommons.org/licenses/by/4.0/). 